Messrs. Lumière gets over this difficulty of the lines by coating a plate with a single layer of starch granules which have been previously suitably coloured in three batches and then well mixed. The disposition of the three required colours is thus irregular, and the separate points of colour are too small to be discriminated by the naked eye. Unfortunately, no example of this method is on view; probably the inventors do not care to show their results until they have perfected the process. But this is the only notable process not represented.

In the rest of the exhibits the three coloured prints are superimposed, the variations being in the methods of their production and assembling. In the Sanger-Shepherd process three separate films are prepared, stained, and cemented together. Several exhibitors have adopted this process, chiefly in the production of transparencies, but there are a few prints on paper, and of these a portrait, No. II, is worthy of special commendation. Dr. B. Jumeaux's modification consists in getting the blue element as a toned bromide print, and then superimposing the red and yellow films. Captain Lascelles Davidson and Mr. O. Pfenninger show specimens in which the films are superimposed but not cemented together, and there are other modifications that are not described.

Instead of three stained films, the prints may be prepared from pigmented tissue by the ordinary carbon process. The Autotype Company, the Rotary Photosraphic Company, Mr. W. E. Brewerton, M. Leon Vidal, the Lumière N.A. Company, and Dr. A. Hesekiel and Co. exhibit prints by various modifications of this method of working, the last named adopting the Selle process introduced several years ago. Mr. W. E. Brewerton shows how the gum bichromate process may be adapted for the purpose, each of the three coloured elements being produced in turn on the same sheet, with no transferring. The two "winter landscapes" by Dr. H. Bachmann are stated to be three-colour prints in gum bichromate, but the colours are scarcely, if at all, perceptible. The "pinatype "process has recently been described in these columns. In this case three colours are absorbed in turn into a single gelatin film from prepared gelatin films previously soaked in the colour solutions. Messrs. Fuerst Bros. show specimens of it, and Dr. E. F. Grün some results of undescribed modifications.

One of the most interesting exhibits is the group numbered from 52 to 56 , examples of coloured prints obtained by a single exposure of a piece of coated paper under the coloured original, the colours being reproduced in the print. The sensitive material has the necessary three colours, each in its own film, superimposed, so that it appears black: By exposure to white light the dyes are all bleached, but if the light is coloured the corresponding colour is not bleached, because the dye does not absorb light of its own colour. This process has been worked at for many years by several investigators, the fundamental difficulties being to find the colours of the right tints that shall be sufficiently sensitive, that is fugitive to light, and can be made sufficiently stable when the print has been produced. These examples are by Szczepanik's method, and show surprisingly bright and clean colours. It is a pity that the original "lithophanes" are not shown as well as the copies, as many will doubtless consider that they are withheld because the comparison would not be to the advantage of the prints. Whether this is so or not, the results are wonderfully good considering the difficulty inherent in such work.

Of the three negatives exhibited by Dr. J. H. Smith and Co., obtained by one exposure in an ordinary camera, the plate used having superimposed on it three sensitive films with the necessary colour screens, there is nathing to be said, as there is no example of the plate used or of the print that the negatives might give. The results on "multico" tissue, which has several layers of pigmented tissue and is used as in carbon printing, the "mars star" prints which are produced by applying colours to bleached bromide prints, and the two portraits by Mr. Burgess can hardly be regarded as serious attempts to reproduce mechanically the colours of the originals until more is known about them. They are better described as colour effects, and there might be some interest attaching to them if the methods of their production were known.

C. J.

\section{THE INTERNATIONAL METEOROLOGICAL} CONFERENCE AT INNSBRUCK.

\section{Fourth Meeting, September .14, $1905 .{ }^{1}$}

THE president, Prof. J. M. Pernter, announced that after the discussion of a proposition made by Father Froc the meeting would proceed to elect the International Committee. By accepting Father Froc's proposition, the committee recommended the observation of the zodiacal light whenever possible, and assigned a definite symbol for use in reports.

On the proposition of Prof. von Bezold, the following committee was re-elected:--Messrs. Chaves, Davis, Eliot, Hellmann, Hepites, Hildebrandsson, Lancaster, Mascart, Mohn, Moore, Palazzo, Paulsen, Pernter, Russell, Rykatcheff, and Shaw.

Also, on the proposition of Prof. von Bezold, Prof. Nakamura, of Japan, was elected in succession to the late Dr. Billwiller.

Prof. Pernter proposed that the presidents of the commissions should be added to the committee, but it was decided that six months' notice should be given of any propositions which would affect the constitution of the committee.

Prof. Hildebrandsson presented the report of the commission on squalls. It was arranged that the question of the study of squalls should be left in the hands of Messrs. Durand-Greville, Hildebrandsson, and Shaw, and that meteorological institutions, including aëronautical stations, should be asked to send to these gentlemen, upon demand, for a certain number of days, about ten per year, the necessary observations for the construction of accurate charts of isobars, with the diagrams of pressure, temperature, and wind for the purposes of this special study.

Prof. Hellmann reported on behalf of the commission on the international code and on the comparison of barometers. The conference considered the publication of the international code, of the resolutions passed by, and of the papers presented to, the international conferences to be a valuable and powerful means of facilitating and developing international meteorological research, and expressed a hope that the meteorological institutions in Berlin, Paris, and London would undertake the publication in German, French, and English. Thanks were voted to Father Algué, who proposed to publish them in Spanish, and to Profs. Hellman and Hildebrandsson for their preparation of the code.

After some discussion as to the best means of comparing the barometers in different countries, it was decided to put into operation the decision of the conference at Vienna relating to the inspection of the stations in the control of each country. The comparison, wherever possible, was to be extended to extra-European countries. This work was left to Prof. Hellmann and General Rykatcheff.

General Rykatcheff presented propositions from the magnetic commission dealing with the necessity of bringing the magnetic instruments in the various observatories into agreement, and with the desirability of an early exchange of diagrams after days of magnetic storms, or whenever the records may be specially interesting.

\section{Fifth Meeting, September 15, 1905.}

The president of the solar commission, Sir Norman Lockyer, presented the report of the meetings of that commission during the preceding days, and also the report of the meeting at Cambridge in 1904. The committee approved of all the resolutions contained in the report, and re-elected the commission, with Sir Norman Lockyer again as president.

The commission expressed the opinion that permanent meteorological observatories should be established in the north of Siberia and America, at least two or three in each country. It also desired to obtain all the observations that may have been made in a large number of islands scattered over the globe, the names of which were given, and insisted on the necessity of continuing these observations, asking that the attention of the Governments concerned should be directed to this matter. Directors of

1 Reports of the proceedings of the first three meetings appeared in NATURE of September 21 and October 5, rgo5 (vol. lxxii., pp. 510 and 562)

No. 1892 , voI. 73] 
meteorological services were asked to furnish data of the heights and flow of rivers and lakes whenever possible.

M. Teisserenc de Bort reported from the commission on the atlas of clouds, and gave particulars of certain alterations in the plates in that atlas and in the definition of stratus cloud.

M. Teisserenc de Bort and Dr. Rotch gave an account of an expedition through the regions of the trade wind and equatorial calms in the North Atlantic. M. de Bort gave the history of the expedition and the results of the observations obtained by means of captive balloons, and Dr. Rotch gave those obtained by kites. Prof. Hergesell followed with the results similarly obtained in the Mediterranean on board the yacht belonging to the Prince of Monaco.

Dr. Köppen announced that the German hydrographical expedition to the Bismarck Archipelago would similarly use balloons and kites during the voyage.

Prof. Mohn reported from the commission on meteorological telegraphy.

M. Polis directed attention to the fact that the Daily Telegraph already announces the coming of storms from the Atlantic, using observations sent by means of wireless telegraphy from ships at sea. The conference then passed the following resolution :- "This conference is convinced that wireless telegraphy is chosen to render in the future great service in the forecasting of the weather in the Atlantic, but before introducing it into the current service of the meteorological institutions it is indispensable to take satisfactory precautions for the control of the observations transmitted. The conference asks the Meteorological Office in London to prepare as quickly as possible a report on this question, and communicate with the other meteorological institutions that may be specially interested in the matter."

During this meeting it was announced that M. Mascart had been elected president, and Prof. Hildebrandsson secretary, to the committee, and that the following commissions had been renewed :-Magnetic commission, president, General Rykatcheff (St. Petersburg); aëronautical commission, president, Prof. Hergesell (Strasburg); solar commission, president, Sir Norman Lockyer (London); commission on radiation, president, Prof. Ångström (Upsala). After thanking the reporters of the various commissions for their reports, the president declared the session at Innsbruck to be at an end.

\section{UNIVERSITY AND EDUCATIONAL INTELLIGENCE.}

OXFORD.-The Vice-Chancellor has appointed Lord Curzon of Kedleston to be Romanes lecturer for 1906.

The following elections have been made to the University mathematical scholarships:-to the senior scholarship, A. Holden (Balliol College); to the junior scholarship, A. V. Billen (University College); to the exhibition, J. Hodgkinson (Jesus College).

u. E. Beaumont (Magdalen College School) has been elected to a natural science scholarship at University College.

Scholarship examinations in natural science will take place on March $1_{3}$ at Keble College, and on April 24 at Merton College, New College, and Corpus Christi College.

Cambridge. - The board of biology and geology has reported to the Senate on the disposition of its share of the Gordon Wigan fund, which amounts to about r $50 l$. The following assignment has been made for 1905 and following years :- (a) A grant of 50 . a year to Dr. D. Sharp, for a period of five years (1905-9), or such part of it during which he holds the curatorship in zoology; $(b)$ a grant of $5 \mathrm{ol}$. out of the income for 1905 to Prof. Hughes, to enable Mr. E. A. Arber to continue his researches into the stratigraphical and geographical distribution of fossil plants; (c) the balance of the fund for 1905, and a grant of $50 l$. for each of the years 1906 and 1907 , to Mr. A. C. Seward, to enable the botanic garden syndicate to offer greater facilities for plant-breeding experiments. The same board strongly recommends that the agreement between the University and Dr. Dohrn, director of the zoological station

NO. I 892 , I OL. 73] at Naples, be renewed for a further period of five years, by the payment to him of $100 l$. per annum out of the Worts travelling bachelors' fund, such period to date from Michaelmas, I906.

Mr. D. G. Hogarth will lecture on "Geographical Conditions affecting Population in the East Mediterranean Lands " in the Sedgwick Museum on Tuesday, February 20, for the board of geographical studies, and Dr. Hans Gadow is to lecture to-day before the Antiquarian Society on "Aztec Civilisation and its Origin."

THE council of the University of Liverpool at a meeting held on January 23 passed the following resolution:"That on the recommendation of the Senate a readership in ethnography be instituted in recognition of the scholarship of H. O. Forbes, LL.D., director of the Public Miseums of Liverpool, and that Dr. Forbes be appointed to the said readership."

IT is announced in Science that $\mathrm{Mr}$. N. W. Harris, of Chicago, has presented $5000 l$. to North-western University, to be used as an endowment for an annual series of lectures to be delivered by some distinguished man, not a professor of the university, upon the results of his own investigations in scientific, literary, economical, or theological problems. From the same source we learn that by the will of Andrew J. Dotger, of South Orange, N.J., the Tuskegee Normal and Industrial Institute will, at the death of the testator's wife, receive the residuary estate, said to be about $100,000 l$.

$I_{N}$ an address delivered to the Manchester section of the Society of Chemical Industry, Dr. G. H. Bailey, as chairman of the section, dealt with the question of higher education and chemical industry, pleading for more cooperation between manufacturers and teachers. If success is to be achieved in the chemical industries of this country, Dr. Bailey considers that there must be a great change in the curriculum hitherto adopted in our universities and colleges; moreover, "a satisfactory curriculum can only be assured by a more intimate association of the teaching authorities, whoever they may be, and the leaders of industry." In considering the present state of English industry and the methods necessary to ensure its prosperity, Dr. Bailey remarks :- " progress in manufacture must indeed be regarded as a safeguard to stability, far more potent than any political or economic device for the protection of interests, and that nation must succeed in industry, which keeps this clearly in view and possesses the talent wherewith to meet the ever changing demands made upon it."

Viscount Hayashr, the Japanese Ambassador, distributed the prizes to the successful students of the Northern Polytechnic Institute, Holloway, on January 25 . In the course of a subsequent address, he said that scientific research made such strides in the past century that it is no exaggeration to assert that the present is the age of practical application in every phase of modern life. Therefore there is nothing more important in a national system of secular education than institutions which keep abreast with the stride of science. Viscount Hayashi explained then that he took part in the administration of the technical college in Tokio. That college was established some thirty years ago with the help of many British professors and men of science whose names are well known in Europe, and from it thousands of students have been sent out to take part in engineering and other works necessitating the scientific application of the mechanical arts. Japan owes very much to that great educational work, and Viscount Hayashi said his people felt grateful for the assistance which Great Britain had given in this department.

THE London County Council School of Marine Engineering at Poplar, which was described in NatuRe for October 19, 1905 (vol. Ixxii. p. 623), was opened on January 24 by Sir William Collins, M.P. An address was delivered by Sir William White, K.C.B., who expressed a favourable opinion of the arrangements, equipment, and course of study provided in the new institute. He went on to describe the remarkable results attained during the last twenty years by a modest educational scheme which he 